
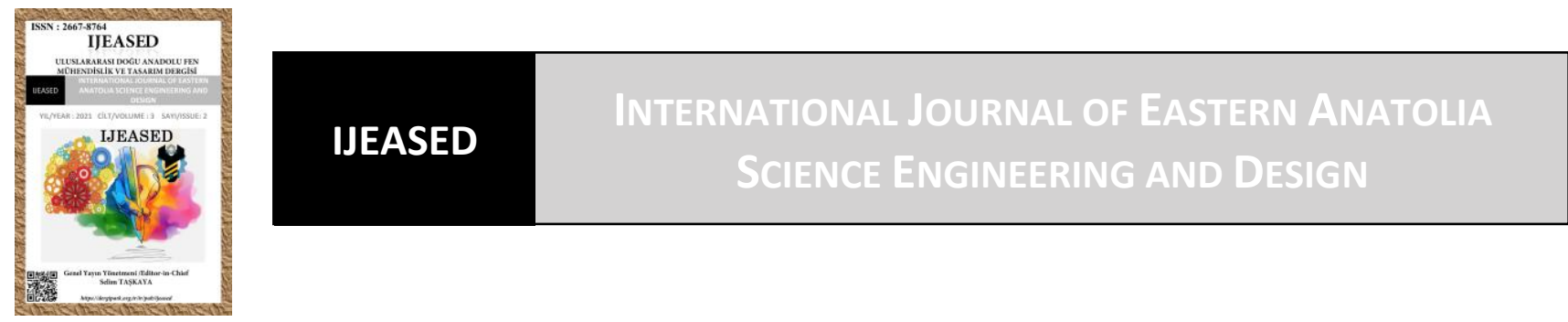

\author{
Uluslararası Doğu Anadolu Fen Mühendislik ve Tasarım Dergisi \\ ISSN: 2667-8764, 3(2), 405-424, 2021 \\ https://dergipark.org.tr/tr/pub/ijeased
}

Derleme Makalesi / Review Article

Doi: $\underline{10.47898 / \text { ijeased.944635 }}$

\title{
Doğa ve Teknoloji Kesişiminde Neri Oxman'ın Tasarım Yaklaşımı
}

\author{
Cengiz TAVŞAN ${ }^{1 a}$, Ayşegül ÇELENK ${ }^{2 *}$, Filiz TAVŞAN $^{1 b}$
}

${ }^{1}$ Karadeniz Teknik Üniversitesi, Mimarlık Fakültesi, Trabzon, 61000, Türkiye.

${ }^{2}$ Gümüşhane Üniversitesi, Mimarlık ve Şehir Planlama Bölümü, Gümüşhane, 29000, Türkiye.

\begin{tabular}{l|l|l}
\hline \multicolumn{1}{c|}{ Yazar Kimliği / Author ID (ORCID Number) } & \multicolumn{1}{|c}{ Makale Süreci / Article Process } \\
\hline "Sorumlu Yazar / Corresponding author : & \multicolumn{1}{|c}{ Geliş Tarihi / Received Date $:$} & 29.05 .2021 \\
aysegulcelenk@gumushane.edu.tr & Revizyon Tarihi / Revision Date : & 21.06 .2021 \\
\hline iD https://orcid.org/0000-0001-8903-751X, A. Çelenk & Kabul Tarihi / Accepted Date : & 16.10 .2021 \\
iD https://orcid.org/0000-0001-5796-6859 , C. Tavşan & Yayım Tarihi / Published Date : & 15.12 .2021 \\
iD https://orcid.org/0000-0001-0674-2844, F. Tavşan & & \\
\hline
\end{tabular}

Alıntı / Cite : Tavşan, C., Çelenk, A., Tavşan, F. (2021). Doğa Ve Teknoloji Kesişiminde Neri Oxman'ın Tasarım Yaklaşımı, Uluslararası Doğu Anadolu Fen Mühendislik ve Tasarım Dergisi, 3(2), 405-424.

\begin{abstract}
Özet
Yaşamın ortaya çıkmasıyla beraber insanoğlunun mimarlık ile doğrudan bir ilişkisi olmuştur. İlkel zamanlarda mimarlık ile insan arasındaki bağ, doğa ile sağlanırken; günümüzde teknolojinin gelişmesiyle farklı parametrelerin kesişmesi sonucunda kurulan değişken bir ilişkiye evrimleşmiştir. Bu bağlamda değişken mimarlık rolünü kurgulayan tasarımcı ve mimarlar yeniliklere yol açarak tasarım yaklaşımlarına farklı fikir ve perspektifler katmaktadır. Günümüzde bu farklılaşma özellikle yeni, karmaşık, çoklu düşünce arayışı ile gerçekleştirilirken, mimari ürünlere yansıma şekli ise malzeme, teknik, üretim ve form gibi tüm süreci kapsayacak bir yenileşmeyi işaret eder. Yenileşmenin iki temel yapıtaşı ise doğa ve teknoloji olduğu görülmektedir. İnsanoğlu doğadan hep ilham almıştır ancak günümüz yeni tasarım yaklaşımlarında doğa sadece formsal bir öykünme olarak değil aynı zamanda teknolojinin getirdiği olanaklarla doğayı anlama, öğrenme, iyileştirme ve geliştirmeye yönelik verilere ulaşılıp kullanılmasına yöneliktir. Günümüz tasarım yaklaşımlarında, teknoloji ve doğa kesişimi önemli bir konudur. Farklı ölçeklerde, multidisipliner bir ortamda geleceğe yönelik çalışmalara kaynak olma düşüncesiyle araştırma yapan tasarımcı/mimarlardan biri de Neri Oxman'dır. Bu makalede, Neri Oxman'ın araştırma grubu ile ürettiği tasarımları doğa ve teknoloji kesişiminde inceleyerek tasarım yaklaşımını (Biyohesaplama) form, biyoloji, teknoloji üzerinden tartışmak amaçlanmıştır. Nitel araştırma yöntemi olan doküman analizi ile Neri Oxman'ın tasarım araştırma ürünleri ile 2007 yılı sonrası biyoloji ve teknoloji kesişimiyle ürettiği mimari ürünler ele alınmıştır. Biyolojik veriler ile dijital araçlar vasıtasıyla ürettiği çalışmaların malzeme, teknik, üretim ve form süreçlerinin birlikte ilerlediği görülmektedir. Bu bağlamda Neri Oxman’ın tasarım düşüncesi ve üretimleri tasarım ve mimarlık alanlarında geleceğe yönelik yenilikçi bir bakış kazandırmaktadır.
\end{abstract}

Anahtar Kelimeler: Teknoloji, Biyohesaplama, Gelecek, Neri Oxman, Tasarım. 


\title{
Neri Oxman's Design Approach at The Intersection of Nature and Technology
}

\begin{abstract}
With the emergence of life, human beings have had a direct relationship with architecture. While the bond between architecture and human beings in primitive times was provided with nature; Today, with the development of technology, a variable established as a result of the intersection of different parameters has evolved into a relationship. In this context, designers and architects who set up the variable architectural role, lead to innovations and add different ideas and perspectives to their design approaches. Nowadays, this differentiation is realized with the search for new, complex and multiple ideas, while the way of reflection on architectural products indicates an innovation that encompasses the whole process such as material, technique, production and form. It is seen that the two basic building blocks of innovation are nature and technology. Mankind has always been inspired by nature, but in today's new design approaches, nature is not only a formal emulation, but also is aimed at reaching and using data for understanding, learning, improving and developing nature with the possibilities brought by technology. In today's design approaches, the intersection of technology and nature is an important issue. Neri Oxman is one of the designers / architects who make research with the idea of being a source for future studies in a multidisciplinary environment at different scales. In this article, it is aimed to discuss the design approach (Bio Computing) through form, biology and technology by examining the designs produced by Neri Oxman's research group at the intersection of nature and technology. With the document analysis, which is a qualitative research method, Neri Oxman's design research products and the architectural products produced by the intersection of biology and technology produced after 2007 were discussed. It is seen that the material, technique, production and form processes of the works produced by biological data and digital tools progress together. In this context, Neri Oxman's design thinking and productions provide an innovative perspective for the future in the fields of design and architecture.
\end{abstract}

Keywords: Technology, Biocomputing, Future, Neri Oxman, Design.

\section{Giriş}

"21. yüzyılın şehirleri bütünüyle farklı olacaklar. Aslında var bile olmayacaklar. Bu akıl almaz yenilik iletişim alanındaki ilerlemelerle, özellikle transistor ve uydular gerçekleşecek... İnanıyorum ki, organik ve biyolojik evrim sonuna yaklaştı ve artık inorganik ve mekanik evrimin başındayız.” Arthur C. Clarke (1964).

Clarke'nin geleceğe yönelik bu söylemi günümüz teknolojinin ne kadar önemli olduğunu vurgulamaktadır. Zamanın evrimleşmesi ve bunu teknoloji gibi yenilikçi bir güçle yapması doğa gibi diğer bir gücü etkilemektedir. Doğanın yaratma özelliği ve kendi içinde barındırdığı sistem insan yaşamı boyunca ilham kaynağı olmuştur. Doğanın etkin olma hali zaman ilerledikçe değişmiş ve gücünü yitirmiştir. Ancak teknolojinin gelişmesi doğanın ilke ve kaynaklarını anlama ve öğrenmeye yönelik bir araç olarak kullanılmaktadır. Teknoloji ve doğanın bu kesişimi özellikle tasarım alanında 21. Yüzyıl içerisinde farklı bir boyut kazandırmıştır. Eski zamanlarda doğa estetik normlara kaynak olurken günümüz ve geleceğe yönelik çalışmalarda doğa sistemini araştırarak, doğayı iyileştirme ve öğrenmeye yönelik yeni yaklaşımlara destek olmaktadır. Özellikle insan yaşamı boyunca doğanın tahribi ve bu tahribin sonucu olarak ortaya çıkan felaket, kirlilik gibi durumlar bu çalışmaların önemini arttırmaktadır. 
Günümüz yenilikçi tasarım yaklaşımları ile çalışmalar yapan Neri Oxman, teknoloji ve biyoloji kesişiminde farklı ölçeklerde ürettiği tasarımları ile multidisipliner bir yöntem geliştiren tasarımcı ve mimardır. Yapmış olduğu çalışmalarda tasarım ve mimarlık alanı haricinde birçok disipline ilham olması ve geleceğe yönelik araştırmaları konu edinmesi yeni bir başlangıca vesile olmuştur. 'Yaşayan konuyu tasarlamak', 'biyolojik yapı' ve 'biyolojik simya' gibi doğa temelli düşünce alt yapısı teknoloji ve bilimi de dahil etmesiyle 'biyohesaplama' yaklaşımını ortaya koymaktadır. Özellikle bu anlayış farklı ölçeklerde ve alanlarda çalışma olanağı tanırken, aynı zaman da ortaya koyduğu 'doğayı koruma, iyileştirme' ilkesinin de önemini vurgulamaktadır.

$\mathrm{Bu}$ çalışmada ise, geleceğe yönelik yapılan tasarım araştırmalarının önemini vurgulamak, Oxman'ın ortaya koyduğu yeni tasarım anlayışını tanımlamak ve örnekler üzerinden doğa, teknoloji ve form üzerinden incelemek amaçlanmıştır. Çalışmada, geleceğe dair yeni tasarım yaklaşımları üzerine çalışan Neri Oxman ve Oxman'ın tasarım sürecinin form, malzeme ve teknik gelişmeleri incelenmiş ve farklı yöntemlerle ürettiği ürünlerin doğa ve teknoloji etkileşimindeki yeri örnekler üzerinden irdelemek hedeflenmiştir. Örnekler biyoloji, teknoloji ve form başlıkları altında incelenmiş ve araştırma ve tasarım örnekleri karşılaştırılmıştır. Bu sayede araştırma ve tasarım alanlarının ilişkisi incelenerek biyohesaplama tasarım anlayışının form üzerindeki etkisi esinlenilen organizmanın malzeme ve formu nasıl etkilediği ve birbirleri arasındaki ilişki üzerinden değerlendirilmiştir.

\subsection{Yüzyıl Mimarlığı ve Doğa İlişkisi}

“Doğa, birbirleri ile etkileşim içerisinde olan örgütlerin bütünüdür” diyen Whitehead, doğanın sürekli bir dönüşüm ve gelişim içerisinde olduğunu ifade etmektedir ve bu durumu süreç olarak tanımlamaktadır (Whitehead, 2017). Tarih boyunca da doğa, hep etkileşim ve gelişim içerisinde olmuştur. İnsanlar önce ihtiyaçlarını karşılamak için doğayı malzeme elde etmek için kullanırken daha sonraları ise ilham kaynağı olarak gözlemlemişlerdir. Zamanla gelişen yaşam şartlarına bağlı olarak da doğa sadece ilham kaynağı olarak değil, malzeme, teknik ve form arayışları için de ilgi duyulan alanlardan biridir.

Doğaya ilgi duyan alanlardan biri olan mimarlık geçmişten günümüze doğayı incelemiş ve kullanmıştır. Marx’a göre “Örümcek, dokumacınınkini andıran bir iş yapar. Arı ise peteğini yaparken birçok mimara parmak 1sırtır" ifadesi ile doğanın barındırdığı kaynağın ne kadar etkileyici olduğunu vurgulamaktadır (Marx, 2015). Doğanın sunduğu imkanlar sayesinde birçok çalışma alanı 
ortaya çıkmıştır. Bu imkanlardan tasarımcı ve mimarlar da faydalanarak tasarımlar geliştirmiştir. Tasarımlar; doğadan öykünme, esinlenme, taklit etme ve benzetme gibi yaklaşımlarla doğayı ele alınış ve uygulanış biçimine göre değişmektedir (Çelenk, 2020).

Zamanla teknolojinin etkisinin artması mimari alanı da etkileyerek yeni arayışlara yönlendirmiştir. $\mathrm{Bu}$ yeni arayışlar doğa temelli düşünce çerçevesi içerisinde dijital çağın entegrasyonuyla yenilikçi yaklaşımlar olarak ele alınmaktadır. Yenilikçi yaklaşımların yeni bir şey üretme haricinde geleceğe yönelik gelişmeler için de önem arz etmektedir. Dünyada yaşanan salgın, kirlilik, tahribat gibi olumsuzluklar sonucunda doğa dengesinin bozulmasın ve kaynak tüketimi gün geçtikçe doğanın önemini arttırmaktadır. Berkebile ve McLennan'ın (2004) geleceğe yönelik söylemlerinde; özellikle 19. yüzyılda popüler olan makineleşmeyi eleştirerek geleceğin çevremizdeki doğanın sunduğu güzelliklerle oluşacağını ve ilham kaynağı olarak geleceği şekillendireceğini ifade etmektedir. Bu sayede makineleşmenin popülerliğinin azaldığı belirterek doğanın gelecekteki önemini vurgulamaktadır.

Doğa ile ilgili çalışmalarda birçok kavram ortaya çıkmıştır. Özellikle doğayı yapısal oluşumu ile taklit etme 1990'lı yıllarla beraber tasarımcı ve mimarlar tarafından sıklıkla kullanılmıştır. Bu kavram; “doğadaki yapılaşmalardan ve oluşumlardan öğrenilmiş/ esinlenilmiş/ modellenmiş/ uyarlanmış ya da uygulanmış" tasarımlar "biyomimesis" kavramıyla tanımlandırılmış ve doğa temelli diğer çalışmalara da ilham olmuştur (Benyus, 1997; Selçuk, Sorguç, 2007). Tarihsel süreç içerisinde doğadan esinlenme ile daha çok form arayışına cevap aranmıştır. Doğadaki formları taklit ederek mimari forma dönüştürülmesi sınırlı bir yaklaşım sağlarken endüstri dönemi ve sonrasında teknolojinin gelişmesi mimarlık alanında da yeni bir boyut kazandırmıştır. Doğanın mimaride yer ediniminin farklı kesitlerde ortaya çıkması "biyonik” kavramı ve yaklaşımını doğurmuştur. Kavram olarak "biyonik (bionic)"; bios (doğa ve yaşam) ile technic (teknik) kelimelerinin kesişimi ile oluşmuştur (Sugar, Leczovics and Horkai, 2017). Doğadaki organizmaların mekanizma ve işlevlerini araştırarak doğal formaların farklı ölçeklerde mimariye dönüştürülmesi üzerine bir yaklaşım olan biyonik mimarlık (bionic architecture), disiplinler arası bir alandır. Doğayı gözlemleyerek doğal teknik ve malzeme kullanarak oluşturulan antik sütun, vernaküler mimari ve Calatrava'nın doğadan esinlenerek oluşturmuş olduğu strüktürel kurgular bu kavramın çerçevesi içerisindedir (Vorobyeva, 2018). Formun analoji yöntemi kullanılarak oluşturulması ancak doğal organizmalara ait tekniğin geliştirilmesi bu kavram için önemli bir noktadır. Tekniğin geleneksel yöntemden evrimleşmesi ise teknoloji sayesinde gerçekleşmiştir. Teknoloji ile beraber sadece doğadan formun bir taklit edinimi değil aynı zamanda sağlamlık gibi teknik çözümler gerektiren bir 
arayışa da yönlendirmiştir. Günümüzde ise doğayı ele alış biçimi daha farklı bir noktaya gelmiştir. Teknolojinin farklı alanlar için çalışma konuları oluşturması ve disipliner ilişkinin de gelişmesiyle doğayı taklit etme değil, doğayı öğrenip anlamaya doğru bir değişim geçirdiği görülür. Doğada var olan bitki ya da hayvan gibi bir gruplaşma haricinde daha çok canlı organizmalar olarak ele alınan doğada, canlı davranışlarını, fizyolojik, biyolojik gibi özelliklerini de incelemektedir. Doğanın ilkelerini öğrenmek ve ona bağlı olarak doğayı iyileştirerek kullanım önem kazanmıştır. Bu durum tasarım alanlarını da teknoloji yardımıyla geliştirmiş ve yenilikçi yaklaşımlar için kaynak olmuştur. 21. Yüzyıl yeniliklerine biyolojik süreçleri tasarıma entegre ederek gelişen bir anlayış ortaya konmuştur. William Myers, "Bio Design: Nature, Science, Creativity" kitabında, biyomimikri kavramının "biyotasarım” olarak tekrar ele almıştır. Doğayı sadece taklit ederek değil aynı zamanda öğrenerek geliştirmenin daha faydalı olacağını savunmuştur. Biyotasarım; alg, bakteri, hayvan ve bitki canlı ve cansız organizmaları materyal olarak ele almaktadır. Böylece sadece bir tasarım ürünü ortaya koymak yerine doğaya faydalı yapı malzemeleri, enerji kaynağı, kirliliğe karşı çözüm üretebilen bir sistem oluşturarak multidisipliner bir çalışma oluşturmaktadır. Biyotasarım yönteminde, biyolojik özelliklerin (yaşam ortamı, reaksiyon şekli, sistematik ilişkiler, fiziksel özellikleri) tanımlanması (Khanzadeh, 2019) dijital tasarım (üç boyutlu analiz ve çizim programları) ve üretim ( $3 \mathrm{~d}$ printer, robotik kollar) araçları sayesinde gerçekleştirilmektedir. Canlı organizmaların hücresel anlamda incelenmesi, davranışlarının takibi ve yer aldığı çevresel koşulların organizma üzerindeki etkisi ve tepkisi dikkate alınarak günümüz tasarım, teknoloji ve doğa ilişkisini ortaya koymaktadir.

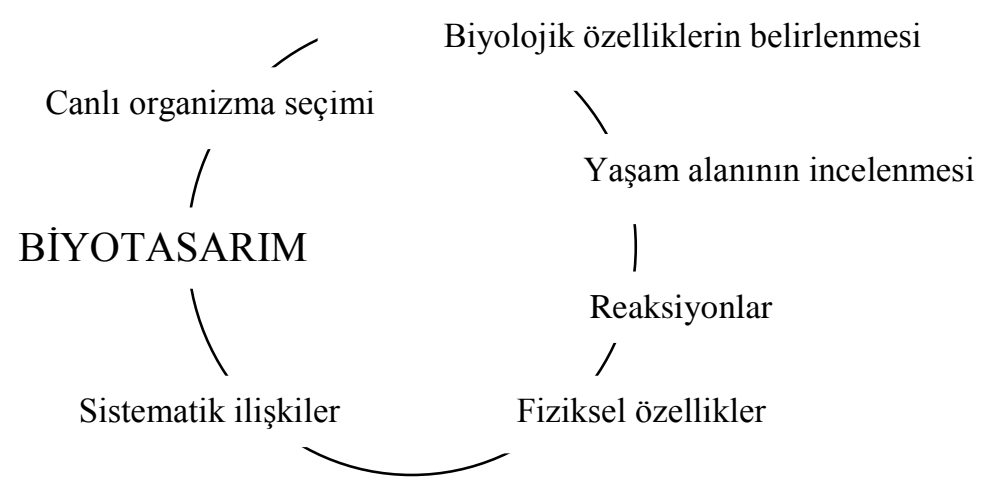

Şekil 1. Biyotasarım Aşamaları (Khanzadeh, 2019)

Doğayı ve teknolojiyi ele alarak tasarımlar yapan biri olan Neri Oxman; doğal dünyanın sınırlamalarını "yeni başlangıçlar olarak kabul edilen sınırlar" olarak düşünür ve "kırmızı meşe ağacının ulaşabileceği yalnızca belirli bir yükseklik vardır çünkü sıvıları pompalayabileceğiniz 
yüksekliğin bir sınırı vardır, ancak baktığımız teknolojiler doğayı artırabilir. Bence makine ve organizma nihayetinde entegre olabilir ve onları zıt olarak görmeyen bir dünya oluşturabilir" ifadeleri ile bu durumu açıklar (URL 1). Burada Oxman; doğadan ilham alarak tasarlanan tasarım ilkelerini kullanarak ve yeni tasarım teknolojileriyle, doğal ve biyolojik çevre arasında köprü kurmayı amaçlamıştır.

Doğadaki sistemlerin belirli bir amacı vardır ve çeşitli işlevler gerçekleştirir. Doğada yer alan biyolojik sistemler, mekansal organizasyon, malzeme, yapısalcılık gibi birçok tasarıma model olmaktadır (Duro-Royoa, ve ark, 2015). Bu modeller, mühendislik, kimyasal, fiziksel, genetik veya geometrik olan tasarım şemasının sentetik sistemlere çevirisi ile hem biyolojik modellerin karmaşıklıklarını yakalayan hem de çok ölçekli tasarım ilkelerini buna uyarlayan karmaşık oluşumlardır. Bu karmaşık oluşumların tasarıma aktarımdaki en önemli araç ise teknolojinin getirdiği dijital sistemlerdir. Bu nedenle geleneksel tasarım yaklaşımlarındaki sınırlı form, malzeme ve teknik çözümlemelerin yerini teknoloji ve doğa temelli kompleks ve yeni yaklaşımlar almıştır.

\section{Materyal ve Yöntem}

Çalışmada, Neri Oxman'ın biyoloji ve teknoloji kesişimi olarak ele aldığı tasarım yaklaşımını (Biyohesaplama) nitel araştırma yöntemi olan dokuman analiz yöntemi kullanılarak incelemek ve farklı ölçeklerdeki örnekleri biyoloji, teknoloji ve form üzerinden irdelemek amaçlanmıştır. Örneklem grubu, tasarımcının web sitesinde yayımlamış olduğu 'projects' kısmında yer alan örneklerden seçilmiştir. $\mathrm{Bu}$ örneklemin seçilme nedeni; tasarımcı grubun esinlendikleri organizmadan biyo-dijital bir üretim yaparak yeni malzeme ve form ilişkisinde farklı tasarım süreçlerini yeniden ele almış olmasıdır. Araştırma kapsamını çizmek amacıyla 21. Yüzyıl mimarlığı ve doğa ilişkisi ve teknolojinin bu ilişki üzerindeki etkisi konu olarak ele alınmıştır.

\section{Teknoloji ve Biyoloji Kesişiminde Neri Oxman}

Steve Jobs; 21. yüzyılın en büyük yeniliklerinin biyoloji ve teknoloji biliminin kesişiminde olacağını ifade etmektedir (Myers, W., 2012:224). 21. yüzyıl teknolojisininin; geleceğe yönelik çalışmalar için önemli bir araç olduğu bilinmektedir. teknolojiye yönelik yapılan araştırmalarda yeni bir dijital yaklaşımın getirdiği olanakları birçok gelişmeye imkan tanıyacağı ve bu imkan doğrultusunda araştırma alanlarının da genişlediği görülmektedir. Mimarlık alanı; günümüz 
çalışmalarında teknolojinin getirdiği olanakları kullanarak diğer disiplinler ile etkileşim halindedir. $\mathrm{Bu}$ etkileşim sonucunda mimari ile diğer disiplinlerin dijital araçlar vasıtasıyla kesişimi farklı fikirlerin doğuşuna yol açarak geleceğe yönelik yeni bir dünyanın kapılarını bizlere açacağı inanılmaktadır (Çelenk, 2020). Bilgisayar teknolojilerinin tasarımcıya sunduğu olanaklar ve sayısal ortamın form üretmede verdiği özgürlük, bir diğer deyişle siber malzemenin tasarımı şekillendirmesi, tasarımın fiziksel malzemeye aktarımında farklı paradigmaları da ortaya çıarak kompleks bir süreç tanımlamaktadır (Sorguç ve Memişçioğlu, 2020). Dijital teknolojiler üzerine çalışan Kolerevich, bu teknolojilerin özellikle son dönemlerde mimari pratiğini değiştirdiğini ve böylece farklı bir yaklaşımın oluştuğunu belirtmektedir (Yiğit, H., 2011). Böylece mimari farklı bir boyut kazanarak yeni arayışlar içerisinde gelişmeye devam etmektedir.

Teknolojinin getirdiği birçok yenilikler bakış açısını genişletmektedir ve böylece farklı disiplinler için çalışma kesiti oluşturmaktadır. Bunlardan biri de doğa üzerine yapılan araştırma alanlarıdır. Doğa ve doğal yapılar, organik ve inorganik birimler üzerinden karmaşık bir sisteme sahiptir. Bu canlı sistemler her zaman tasarımcılara ilham olmuştur. Doğa ve teknoloji üzerine çalışan tasarımcı ve mimarlardan biri de Neri Oxman'dır.

Oxman, doğayı tüketmekten onu güçlendirme, yapılı çevreyi tasarlama ve inşa etme türüne köklü bir değişim çağrısında bulunarak yenilikçi bir yaklaşım önermektedir. Önerdiği yaklaşım multidisipliner bir kesişimi olan ve daha önce imkânsız gözüken tasarım yöntemleri üretmektedir. $\mathrm{Bu}$ durumu oluştururken ise doğadan ilham alarak oluşturmaktadır. Akademik çalışmalarını yürüttüğü Massachusetts Teknoloji Enstitüsü'nün Medya Laboratuvarı'nda da ilham aldığını doğayı hesaplamalı tasarım, mimari, deniz bilimi, mühendislik, fizik ve biyoloji gibi farklı disiplinleri bir araya getirerek yenilikçi bir tasarım pratiği ortaya koyarak gerçekleştirmektedir. Bu çalışma pratiğinde farklı ölçeklerde çalışarak dijital form bulma yöntemleri ile doğadan elde edilen verileri dijital üretim ve tasarlama araçları vasıtasıyla geliştirmektedir.

Oxman; "Dijital teknolojiler yalnızca resmi hedeflerimize hizmet edemez ve hizmet etmemelidir" diyor. Periyodik tabloyu genoma bağlamak için artık malzemelerin kimyasal ve fiziksel özelliklerini hesaplayabiliriz. Moleküler biyologlar artık DNA kodunun parçalarını örneğin tasarımcılarla paylaşabilirler. Yalnızca metaforik değil aynı zamanda açık bir ortak dil yaratır. Bu yeteneğe daha önce hiç sahip olmadık. " ifadeleriyle de yeni bir süreci tanımladıklarını vurgulamaktadır (URL 1).

$\mathrm{Bu}$ bağlamda ekibi ile gerçekleştirdiği 'materyal ekolojisi' yaklaşımı ise inşa edilmiş, büyümüş ve güçlendirilmiş arasındaki ilişkileri araştıran, bilgilendiren ve ifade eden bir tasarım 
felsefesi, araştırma alanı ve bilimsel yaklaşımdır (URL 2). Daha önce imkânsız görünen tasarım yaklaşımlarını araştıran, malzeme, ekoloji ilişkisinin tasarım ve mimarlıktaki etkisi üzerine yaptığı modeller ile de bu yaklaşımı geliştiren bir süreç ortaya koymuştur. Geleceğe yönelik olan çalışmalara imkân veren yaklaşımlar üzerine çalışan Oxman, uzay çalışmalarından iklim değişikliği gibi alanlarda doğayı kullanarak, geliştirerek ve ilham alarak çalışma perspektifini geliştirmektedir.

Oxman ve ekibi tarafından geliştirilen yenilikler, mikroorganizmaların "fabrikaları" ve temel biyolojik özelliklerinde stratejik olarak artırılmış malzemeleri taklit edecek şekilde tasarlanabileceği yeni bir "biyolojik simya" çağını mümkün kıldığı görülmektedir. Bu teknolojiler, neredeyse her biyokütlenin giyilebilir giysilerin üretiminden bina yapımına kadar çeşitli amaçlarla kullanılmak üzere biyomalzemelere dönüştürülebildiği tasarım ve üretim için radikal bir yeni yaklaşım sunarak yenilikçi yaklaşımlara örnek olmaktadır.

Bu bağlamda doğanın sadece malzeme sağlamadığı aynı zamanda o malzemenin nerede ve nasıl kullanılacağı hakkında da bilgi verdiği görülmektedir (Kallegias ve Erdine, 2015:513).

\section{Neri Oxman ve Tasarım Yaklaşımı}

Mimari tasarım tarihinin uzun yörüngesinde, eserlerin tasarımı ve üretimi şekil ve madde arasında artan bir ayrımla karakterize edilmiştir. Materyal ve formun, bir yapım geleneğine organik olarak iç içe geçtiği zanaatın aksine, modern tasarım ve üretim, tarihsel olarak bu entegrasyondan uzaklaştığında, ya da yokluğunda, form yapımının kaynaklarından bağımsız bir süreç olarak bölümlendirilmesine doğru gelişmiştir (Sennett, 2013).

“İnanıyorum ki, yakın gelecekte binalarımızı ve evlerimizi üç boyutlu olarak basacağız.” Neri Oxman, 2020 (URL-14).

Neri Oxman'ın tasarımlarından Monocoque, Raycounting, Cartesıan Wax, Vespers I, Vespers II, Vespers III malzeme, form ve teknik üzerine yapılan araştırma ürünleri ve Aguahoja, Silk Pavilion I, Silk Pavilion II, Living Mushtari ve Gemini isimli çalışmaları ele alınmıştır.

Monocoque; yüzeyi heterojen malzeme ve form dağılımıyla oluşan bir tasarımdır. Tasarım, bir yumurta kabuğuna benzer şekilde nesnenin diş cildi olarak desteklenmektedir. Dijital tasarım süreciyle, kaplama unsurlarını gerilime ve basınca dayanıklı olarak geliştirilmiştir. Bu süreçte kullanılan yenilikçi 3B baskı teknolojisi, tasarımcıların birden çok malzemeden yapılmış parçaları ve montajları tek bir yapı oluşmasına imkân doğurur. Her bir boşluk, formu oluşturan bir doku meydana getirmiştir. 


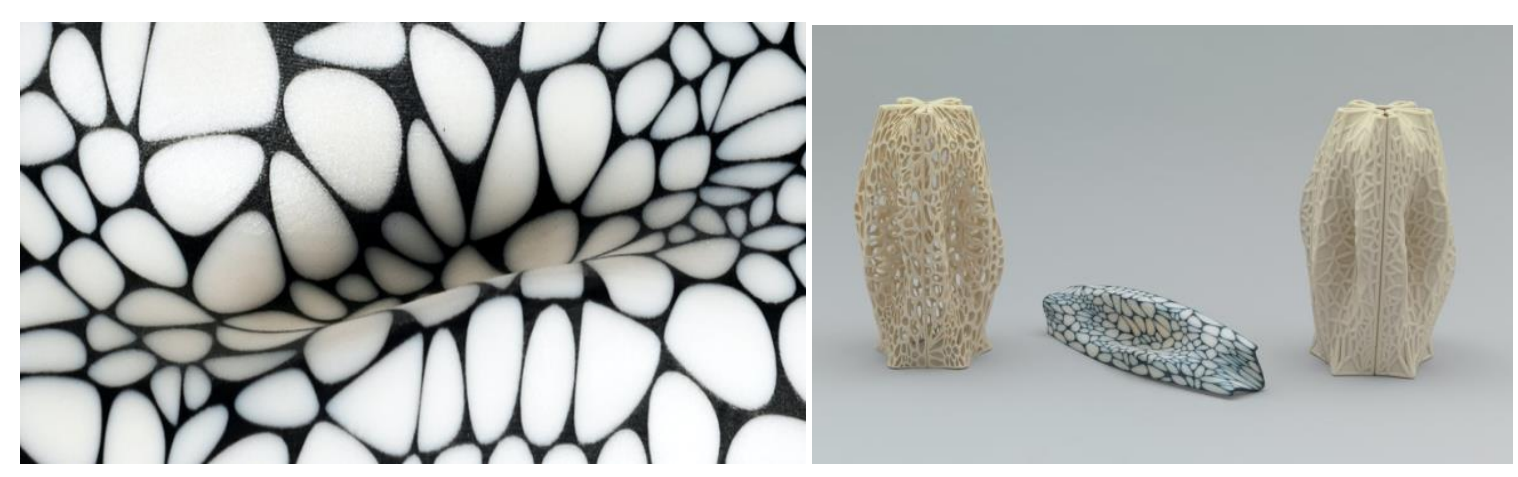

Şekil 2. Monocoque Yüzeyi ve Formu (URL-3)

Raycounting; yüzeylerin eğimli oluşu ve farklı 1şık-gölge etkisiyle tasarım oluşmaktadır. 3D model yazılımlarının analizi ile geometri oluşturulmuş, daha sonra da derinlik kazandırmak amacıyla da farklı perspektifler tasarımı biçimlendirmiştir. Böylece ışığın yönünü ve yoğunluğunu gölgelendirmeler ile kaydederek şeffaf bir yüzey geliştirilmiştir.
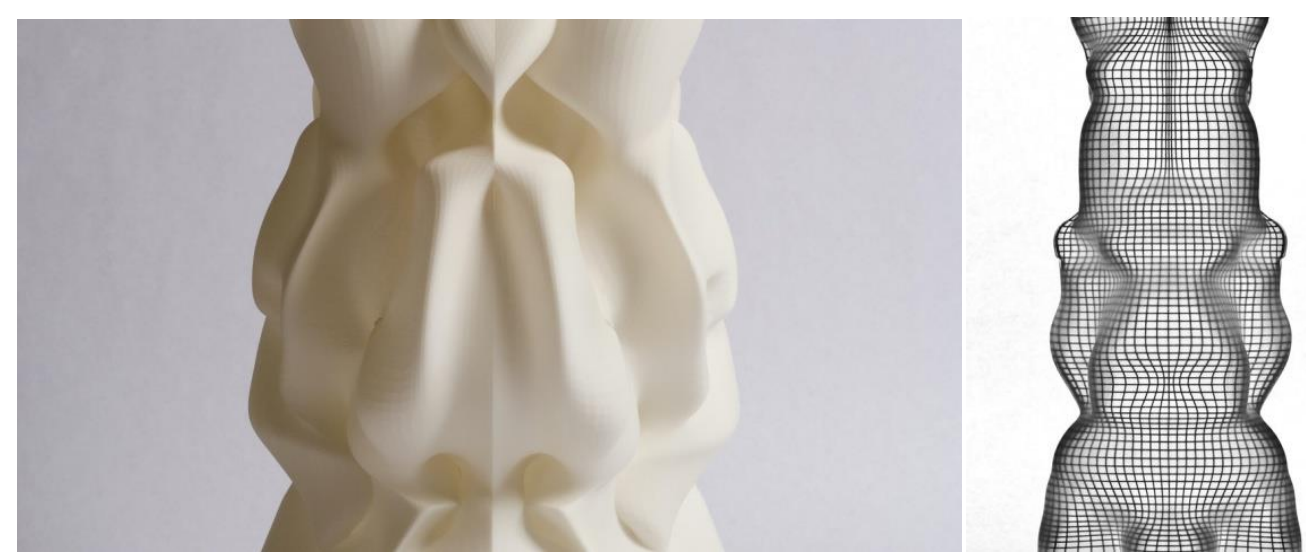

Şekil 3. Raycounting Kıvrımlı Formu (URL-4)

Cartesıan Wax; çok işlevli ve çok malzemeli yapısal bir yüzeydir. Descartes'in Kartezyen Balmumu tezinden esinlenerek geliştirilmiştir. Descartes'a göre, balmumunun özü, balmumunun fiziksel biçimindeki çeşitli değişikliklerden sağ kurtulan bir üründür. İşlevine göre kalınlığı değişerek fonksiyon kazandırır. Tek bir ayarlanabilir kalıptan dökümle beraber yüksek sıcaklıkta dövülerek sertleştirilmiş bir süreç geliştirilmiştir. Farklı varyasyonlar denenerek ölçek değişikliğindeki fiziksel özellikleri incelenmiştir. 


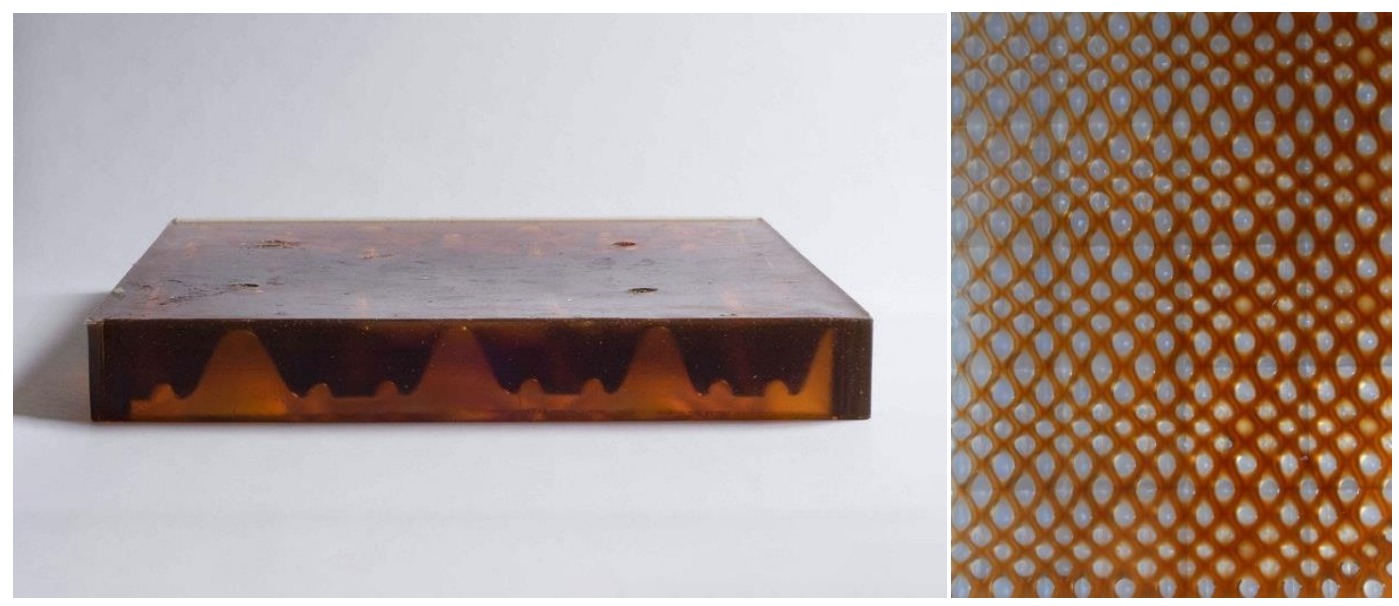

Şekil 4. Cartesian Wax (URL-5)

Vespers I; yaşamı ölüm merceğinden inceleyerek bir araştırma konusu oluşturulmuştur. Antik maskelerden esinlenerek, bölgeler ve çağlar boyunca dini uygulamalarda yaygın olarak bulunan beş renk kombinasyonunu kullanmış ve bizmut, gümüş ve altın gibi doğal minerallerle maskeler geliştirilmiştir. Antik Mısır'dan etkilenerek maskelerin renkleri belirli bir parametrik dil oluşturur. Yaşamın oluşumunu yansıtarak yaşam-ölüm sürecini farklı eğimli ağ sistemi uygulayarak hücresel bir algoritmik bir yüzey tasarlayarak; evrimleşir. Bu süreç katmanlı bir üretimi tanımlar.
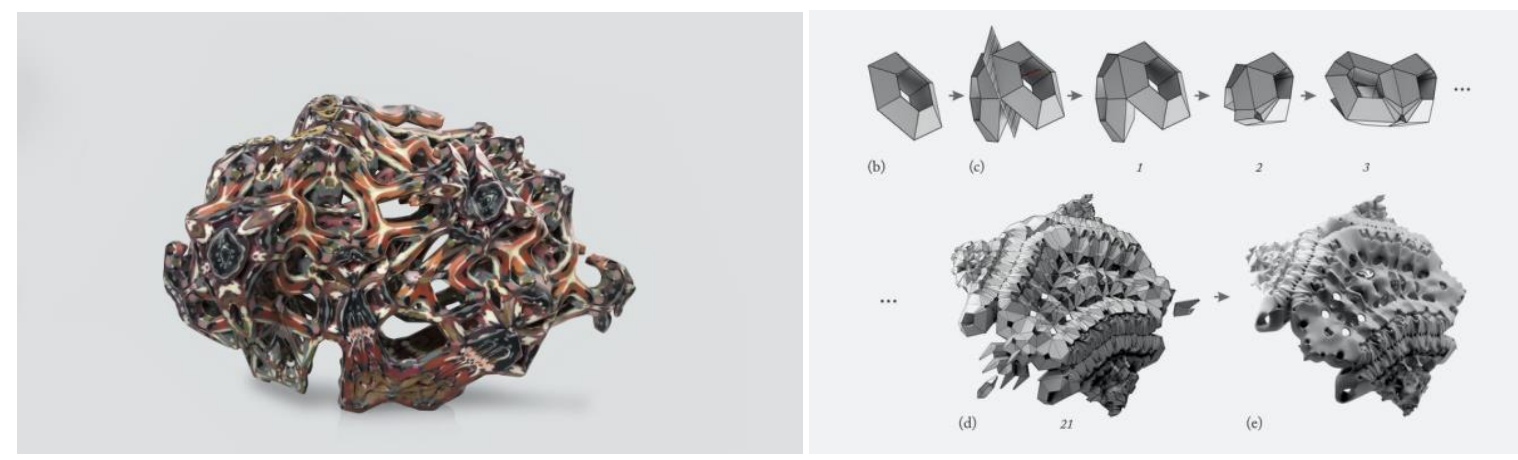

Şekil 5. Vespers I ve Tasarım Alternatifleri (URL-6)

Vespers II; Antik yaşamdan etkilenerek ölüm maskesi geleneğini yansıtmak istenen tasarımda, ölen kişinin ruhunu güçlendirerek kötülüklerden korunduğuna inanılmaktaydı. Ruhun yeni bir yaşama ilham verileceği düşünülerek ruhun nefes olma hali ele alınmaktadır. Tasarımı oluşturmak için heterojen bir süreç izlenmiştir. Bu karmaşık ve farklı detaylar içeren tasarımda 3D baskılar kullanılmış, maskenin parçalarında farklı renk entegrasyonu ile tasarım şekillendirilmiştir. Geleneğin çağdaş yorumu ile maske bir başkalaşım yaşayarak ölümden yeniden yaşama geçişi temsil etmektedir. 

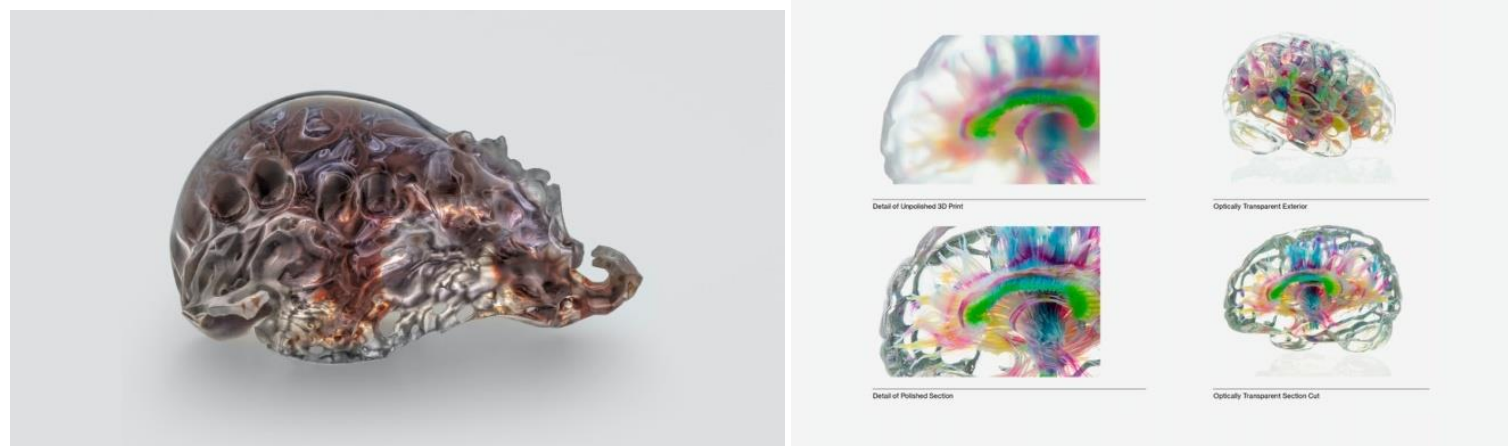

Şekil 6. Vespers II (URL-7)

Vespers III; mikroorganizmaların kullanıldığı ve yeni yaşamı destekleyen bir tasarımdır. Bu maskeler ilki gibi ruhsal etkiyi hem de ikinci tasarımdaki biyolojik sürecin kesişimiyle oluşturulmuştur. Canlı organizmalardan 3D araçlarla analiz yaparak biyolojik malzeme araştırılması yapılmıştır. $\mathrm{Bu}$ nedenle, hesaplamalı ve dijital üretim araçları, maske içinde bulunan mikroorganizmaların büyümesini ve ifadesini yönlendirmek için özelleştirilmiştir. Dijital araçların desteği ile yaşayan bir organizma ile bir maske üretimi gerçekleştirilmiştir. Tasarım, nöro-vasküleri temsil eden damarlardan gerçek biyolojik kavanozlara geçiş yaparak yeni bir yaşam döngüsüne işaret etmektedir.

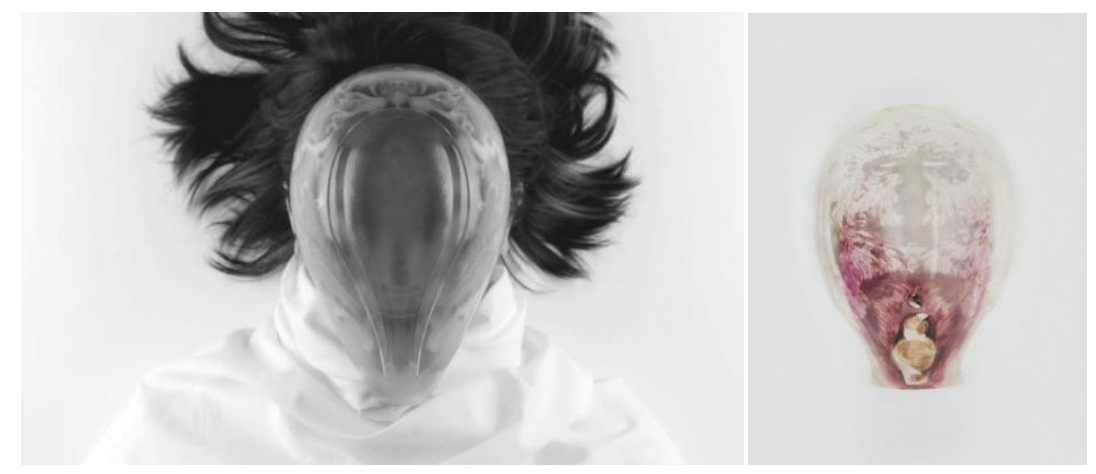

Şekil 7. Vespers III (URL-8)

Neri Oxman'ın farklı ölçeklerdeki çalışmaları, planladığı diğer çalışmaları desteklemektedir. Özellikle yeni malzeme üzerine yaptığı araştırmalarda, küçük ölçeklerdeki üretimleri, malzemenin farklı ortamlardaki davranışını incelemek ve geliştirmek için uyguladığı bir yol olduğu söylenebilir. $\mathrm{Bu}$ küçük ölçekli çalışmaları daha çok araştırma odaklıyken bazı çalışmaları ise canlı organizmaların fiziksel davranışlarını keşfetmek ve bu davranışları ile dijital araçlar vasıtasıyla yepyeni bir tasarım süreci tanımaya yönelik olduğu görülmektedir. Bu çalışmalardan biri Aguahoja 2019, suyun harici gücü tarafından geliştirilmiştir. 
Aguahoja; denizden elde edilen ve toprakta çürüme yerine yeniden kullanılarak yeni bir malzeme dokusundan üretilen bir tasarımdır. $\mathrm{Bu}$ tasarımda çevresel kirliliğin yarattığı olumsuzluklar ve dönüşebilen malzemelerin önemi vurgulanmaktadır. Doğadaki organik yapıların diğer yapay malzemelere göre daha verimli olduğu ve bu malzemelerin çevresel bir zararı olmaması tasarımdaki önemli noktalardan biridir. Selüloz, kitin ve pektin gibi doğadan elde edilen malzemelerin laboratuar ortamında geliştirilmesi tasarım süreci içerisindeki malzeme, form ve tekniğin kesişimini gerektirmektedir. Ayrıca bu malzemeler bulundukları doğal çevrenin kazandırdığg özellikleri yani dayanıklılıkları, sürdürülebilirlikleri ve uyarlanabilirlikleri ile yenilikçi düşünceyi de beslemektedir. Aguahoja, mekanik, optik, koku alma ve hatta tat özellikleri ile ayarlanabilir özellikler sergileyen biyopolimer kompozitlerin oluşturulması yoluyla toksik atık döngüsünü bozan plastiğe alternatif bir malzeme sunmaktadır. Yaprak formlardan oluşan pavilyon, zamanla kaplandığı malzemenin değişmesiyle kabuk yüzeyinde dönüştüğü görülmektedir. $\mathrm{Bu}$ durum yapının oluşturulduğu yap1 malzemesinin dönüştürülerek oluşturulması ve tekrar kullanımına yönelik bir yaklaşım olduğu görülmektedir. Dijital araçlarla tasarlanan ve oluşturulan Aguahoja, büyüme ve ayrışma yoluyla, organizmaların sürecinin somutlandırılmış hali olarak forma yansimaktadir.
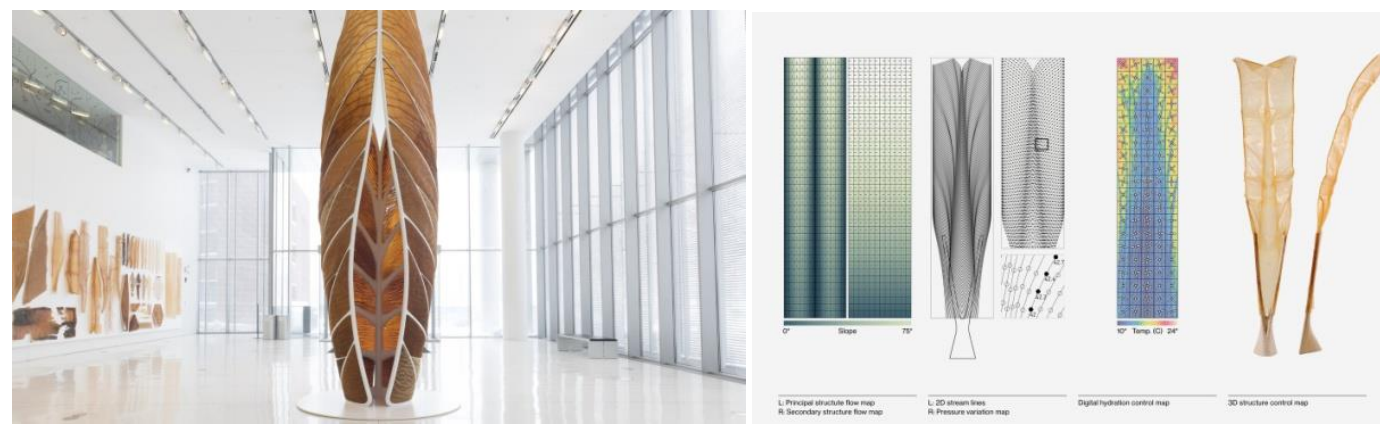

Şekil 8. Aguahoja ve formun kademeleri (URL-9)

Silk Pavilion I; doğal kaynakları tüketmeden yeni malzeme üreterek sürdürülebilir bir yaklaşımla oluşturulmuştur. Biyoloji ve teknolojinin ortak çalışmasıyla geleceğe yönelik çalışmalar için farklı bir adım atılmasına destek olan Silk Pavilion I projesi, canlı ipek böceklerinden bir yapı tasarımının nasıl süreçlerden geçtiğini araştırmaktadır. İpekböceğinin davranışı, izlediği yolu ve ördüğü ipek ipi ile de hem malzeme hem de tasarım sürecine yönelik ciddi bilgiler vermektedir. Dijital araçlarla oluşturulmuş olan yapısal iskelete ipek böcekleri yerleştirilerek farklı yoğunlukların oluşması için izlenen 1şık ve 1sıdaki değişimler formun oluşumunda etkili olmuştur. 


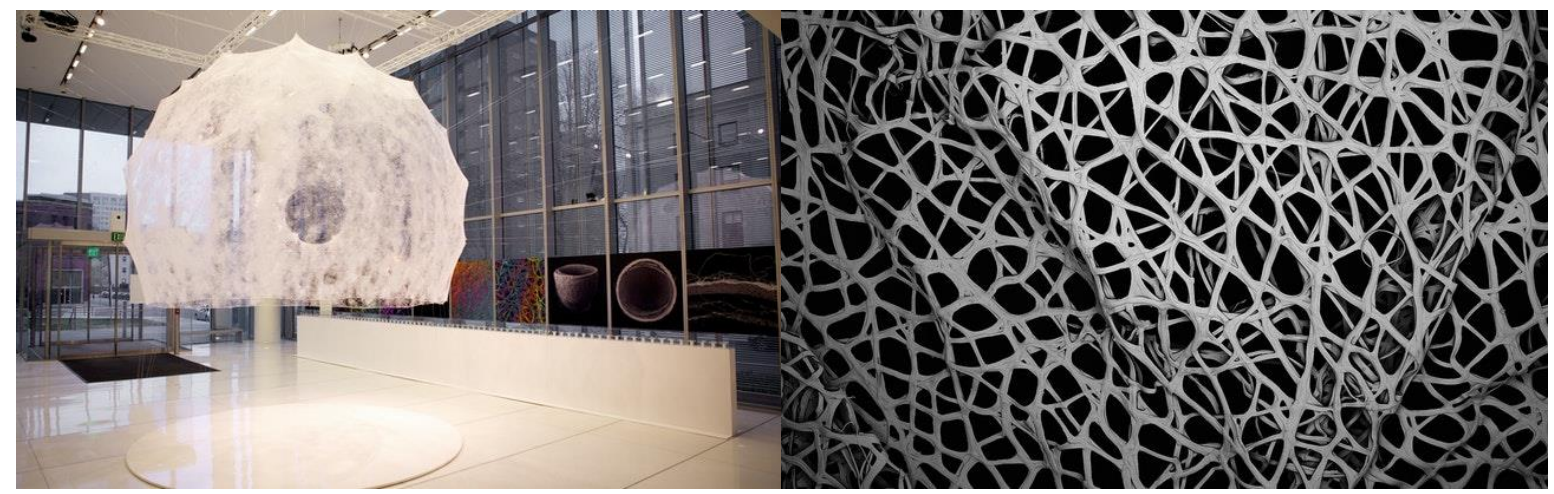

Şekil 9. Silk Pavilion I (URL-10)

Çalışma, ipekböceğinin eğirme davranışı, malzeme ve yapısal karakterizasyonu, hesaplamalı simülasyon ve Pavyon'un tam ölçekli inşası için tasarlanan fabrikasyon stratejileri hakkında temel araştırmanın bir incelemesini sunmaktadır. Biyolojik üretimi içeren büyük ölçekli fiber tabanlı dijital fabrikasyon için potansiyel uygulamalara referans olmaktadır (Oxman, 2014).

Silk Pavilion II; Silk Pavilion I'in farklı bir varyasyonudur. İpek böceklerinin 1şık ve 1S1 yoğunluğuna göre 10 günlük zaman dilimindeki hareketlerini incelemek ve ipek böceğini öldürmeden ipek ipini elde etmek için pavilion dijital araçlarla oluşturulmuş ve teknoloji ve biyoloji kesişiminin bir ürünü olarak ortaya çıkmıştır. Silk Pavilion II'de ipek böceğinin başkalaşım sürecinin tamamını kapsayarak kimyasal reaksiyonların malzemenin oluşturmasına izin vermektedir.

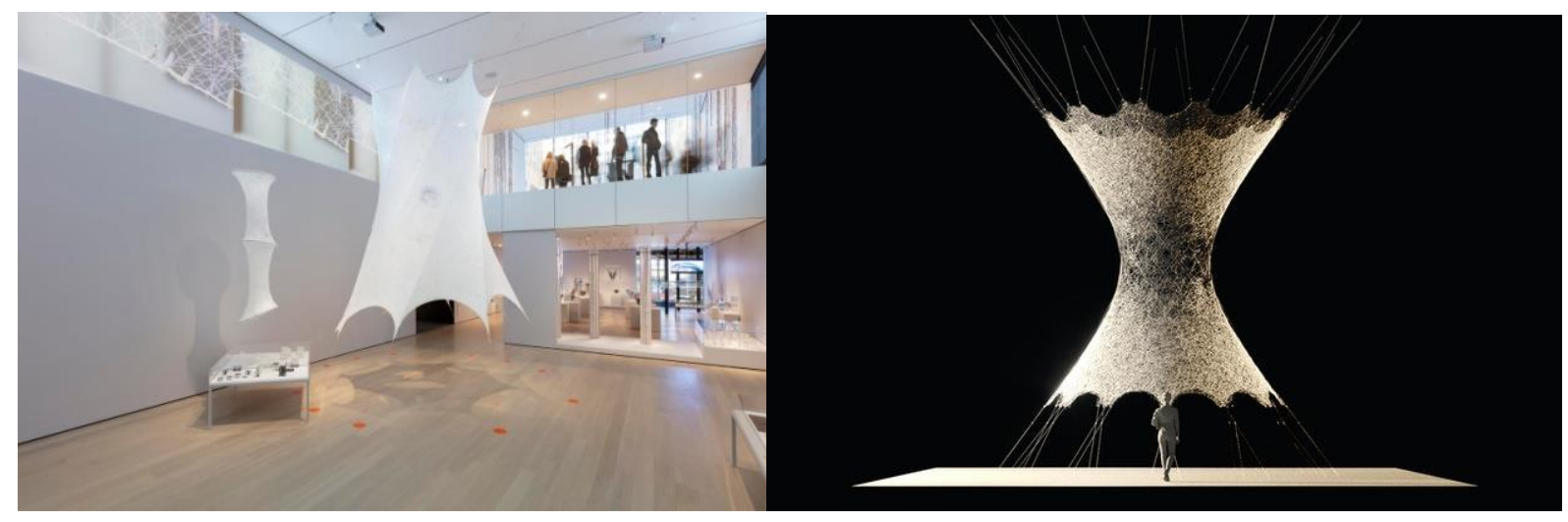

Şekil 10. Silk Pavilion II (URL-11)

Living Mushtari; iki mikroorganizma olan mikroalgler veya siyanobakteriler gibi fotosentetik bir mikrop ve ekmek mayası bakterisinin simbiyotik ilişkisi sonucunda güneş ışığını kullanarak dönüştüren giyilebilir bir cihazdır. Üretken bir algoritmik sistemle tasarlanan bu tasarım, 
parçalarındaki dokunun heterojen dağılımıyla fiziksel özelliklere göre değişkenlik gösterdiği görülmektedir. Sentetik, şeffaf ve renk değiştiren Living Mushtari, 3d yazıcılarla oluşturulmuştur.

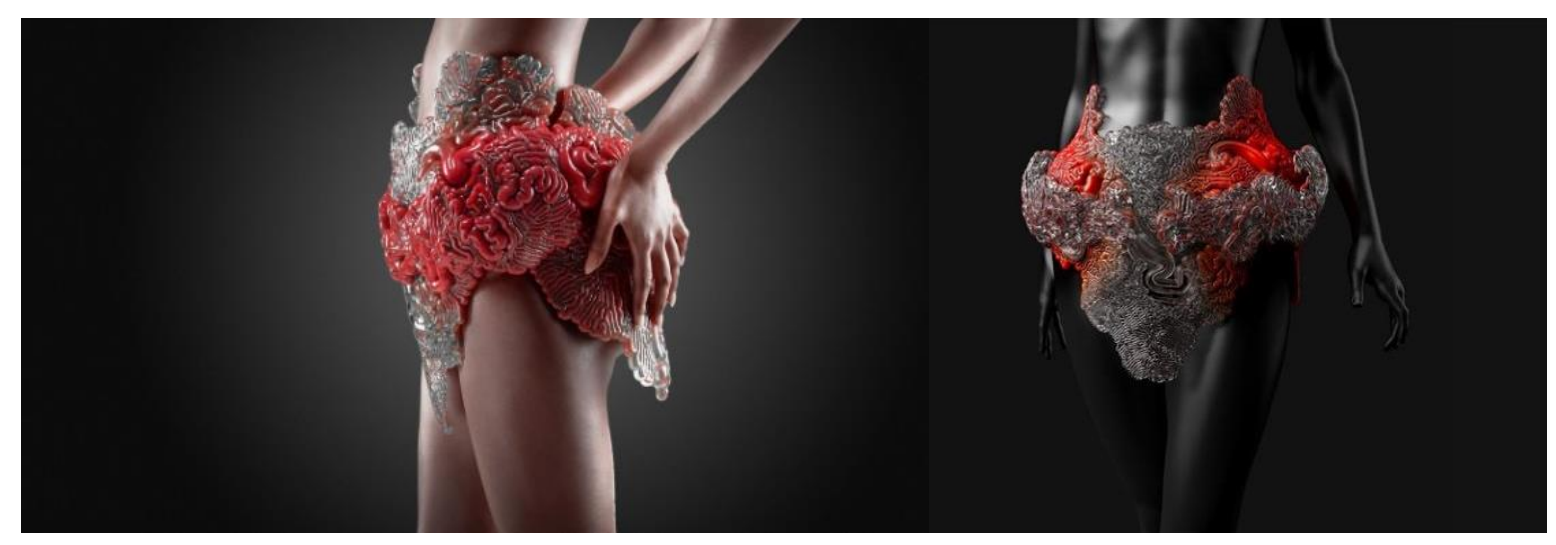

Şekil 11. Living Mushtari (URL-12)

Dijital büyüme için gelişmiş hesaplamalı tasarım stratejilerini çoklu malzeme ile birleştirerek 3d baskılarla çok işlevli mekansal-zamansal değişim ile tasarıma "nefes alma" ve "yaşama" özelliği katarak çevresel etkileşime girebilen giyilebilir cihazların oluşturulmaktadır (Bader, ve ark.,2016).

Gemini; tasarım çıkış noktası astrolojideki bir hikâyeye dayanmaktadır. Tasarım sürecinde farklı ikilemleri barındırarak karşıtların bir araya gelmesiyle farklılaşmaktadır; sonik ve güneş ortamları, doğal ve sentetik malzemeler, sert ve yumuşak duyumlar, ayrıca eksiltici ve eklemeli üretim. Sessiz, korunaklı bir ortam oluşturmayı amaçlayan Oxman; şezlongu karmaşık ve hücresel bir iç kabuğu olan rahme benzetmektedir. Oluşturulan yüzey dokusundaki farklı malzeme ve ölçülerin oluşturduğu geometrinin korunaklı bir akustik ortam oluşturduğu düşünülmektedir. Dijital araçlarla tasarlanan ve üretilen Gemini; dijital malzemeler yardımıyla sesi emerek fonksiyonel bir özellik kazanmaktadır. 

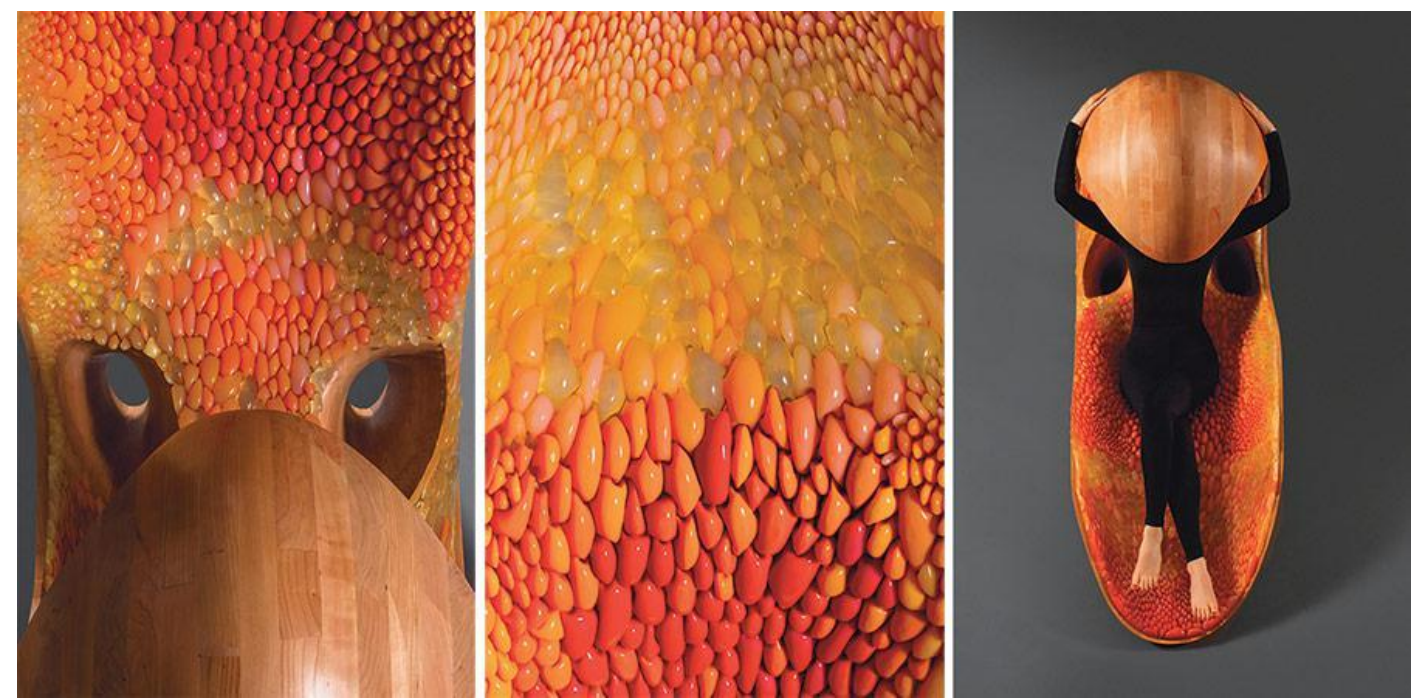

Şekil 12. Gemini (URL-13)

Geleceğe yönelik araştırmalar, iyileştirmeye odaklanarak mikro ve nano ölçeklerde malzeme karmaşıklığından esinlenerek yüksek çözünürlüklü kompozit malzeme üretmek için doğal malzeme yapıları geliştirmeye yönelik olacaktır (Oxman, 2015). Oxman'ın biyoloji temelli dijital üretimleri sadece canlı sistemleri tasarım uygulamasına dahil etmek ile ilgili değil, aynı zamanda canlı sistemlerdeki hücrelerin işleyiş ve davranış şeklini bir bütün olarak değerlendirerek tasarlamakla ilgilidir.

Oxman'ın ele aldığı biyotasarım; biyoloji temelli bir tasarım yaklaşımıdır. Teknolojinin gelişmesiyle tasarımda karmaşık oluşumların algılanmasına yardımcı, doğa destekli bir anlayış benimsenmiştir. Teknoloji ile beraber dijital üretim ve tasarım araçlarının dahil olması hesaplamalı tasarımın oluşmasına, zamanla doğa ile teknoloji ilişkisinin artmasını sağlamıştır. Bu durum “biyohesaplama” alt kavramı ile multidisipliner bir araştırma ortamı geliştirmiştir. Biyohesaplama; biyoloji ve teknoloji kesişiminde malzemeyi, tekniği ve formu etkileyen bir yaklaşımdır. Doğadan ilham alınan organizmanın biyolojik özelliklerinin kullanıldığı ve elde edilen verilerin dijital ortamlarda analiz edilerek hesaplamalı tasarım süreciyle geliştiği bir alan oluşturmaktadır. $\mathrm{Bu}$ bağlamda Oxman'ın araştırma alanlarını etkileyen ve tasarım düşüncesini oluşturan bu yaklaşım; doğayı teknoloji kullanarak geliştirmeyi hedeflemektedir. Örneklerde görüldügü üzere form oluşumunda biyolojik esinlenme haricinde yine o biyolojiden elde edilen malzeme ve yapısal özelliklerin önemi vurgulanmaktadır. Araştırma örneklerinin biyolojik verileri kullanma şekilleri tasarlanan diğer üretimler için referans olmaktadır. Bu bağlamda araştırma ve tasarım grubunun birbirlerini besleyerek tasarım süreçlerini geliştirmeleri geleceğe yönelik araştırma alanları için yol göstermektedir. Multidisipliner bir çalışma alanının gerekliliği de Oxman'ın üretimlerinde net bir şekilde görülmektedir. 
Biyotasarım aşamalarından olan: canlı organizma seçimi, biyolojik ve fiziksel özelliklerin tanımlanması, reaksiyonları "biyoloji” başlı̆̆ı içerisinde, hesaplamalı yaklaşım olarak "teknoloji”" başlığında elde edilen tasarımların üretim yöntemi incelenerek bu iki başlık sonucunda kazanılan form ve özellik nitelikleri irdelenmektedir. Araştırma örnekleri, bu sürecin gelişmesindeki adımlarını ortaya koyarken ikinci bölümde ise, önceden elde edilmiş verilerden tasarım örnekleri geliştirilerek fonksiyonel bir ürün elde edildiği görülmektedir.

Oxman'ın araştırma ve tasarım örneklerinde elde edilen ilişki biyohesaplama yaklaşımı ile form üzerinden okunmaya çalışılmaktadır. Canlı organizmaların biyolojik ve fiziksel özellikleri, yaşam alanlarında kurdukları ilişki ve verdikleri reaksiyonlar sonucu form, malzeme ve kazandırılan özellikler (kir tutmama, enerji dönüşümü gibi) araştırma tabanını oluşturmaktadır. Böylece tasarım ürünleri için bir referans olmakta ve biyohesaplama yaklaşımı ile alternatif öneriler sunmaktadır.

Aşağıdaki tabloda araştırma örnekleri; Monocoque, Raycounting, Cartesıan Wax, Vespers I, Vespers II, Vespers III malzeme ve özellikler üzerine bir çalışma sunarken, tasarım örnekleri Aguahoja, Silk Pavilion I, Silk Pavilion II, Living Mushtari, Gemini ise malzeme ve özelliklerin biyolojik referanslarla forma etkisini yansıtmaktadır.

Araştırma organizması olarak kullanılan yumurta kabuğu, deri, balmumu özü, mineraller, nöro-vesküler ağlar üzerinden malzeme ve özellik geliştirilerek tasarıma davranış niteliği kazandırma amacı taşımaktadır. Tasarım örneklerinde yer alan deniz kabukları, ipek böceği, alg ve bakteriler, rahim gibi organizmalar için araştırma örnekleri veri özelliği taşımaktadır. Böylece biyohesaplama sürecinde araştırma ve tasarım adımlarının beraber geliştirildiği ve değişebilir özelliklerle yeniden ele alınabileceği görülmektedir. Biyolojik süreçlerin hesaplamalı tasarım ile malzeme ve teknik haricinde organizma davranışlarının da tasarıma kazandırılarak yenilikçi bir kazanım elde edilmektedir. Bu durum, farklı ortam ve durumlarda değişken ve alternatif tasarımların geliştirilme imkanının olduğunu göstermektedir. Doğada yer alan organizmaların davranışlarının anlaşılması ve araştırma konusu olarak sadece taklit etme değil aynı zamanda o organizmayı tasarıma entegre amacı taşıması, fiziksel özellik olarak tasarım formu üzerinde net bir şekilde okunmaktadır. 
Tablo 1. Neri Oxman'ın Tasarım Üretimlerinin Biyoloji, Teknoloji ve Form İlişkisi (Yazar Tarafından Oluş̧urulmuştur)

\begin{tabular}{|c|c|c|c|}
\hline & $\begin{array}{l}\text { Biyoloji } \\
\text { (Organizma) }\end{array}$ & $\begin{array}{l}\text { Teknoloji } \\
\text { (Üretim) }\end{array}$ & Özellik \\
\hline \multirow{3}{*}{ 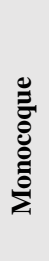 } & \multirow[t]{3}{*}{$\begin{array}{l}\text { Yumurta } \\
\text { Kabuğu }\end{array}$} & \multirow{3}{*}{$\begin{array}{l}\text { 3D Yazılım } \\
\text { 3D Bask1 }\end{array}$} & $\begin{array}{l}\text { Heterojen } \\
\text { Yüzey } \\
\text { Malzeme }\end{array}$ \\
\hline & & & Form \\
\hline & & & Hücresellik \\
\hline \multirow{3}{*}{ 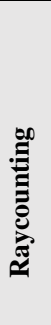 } & \multirow[t]{3}{*}{ Deri } & \multirow[t]{3}{*}{$\begin{array}{l}\text { 3D Yazılım } \\
\text { 3D Baskı }\end{array}$} & $\begin{array}{l}\text { Şeffaflık } \\
\text { Derinlik } \\
\text { Işık } \\
\text { Gölge }\end{array}$ \\
\hline & & & Form \\
\hline & & & Eğrilik \\
\hline \multirow{3}{*}{ 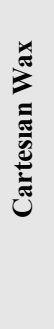 } & \multirow{3}{*}{$\begin{array}{l}\text { Balmumu Özü } \\
\text { Deri }\end{array}$} & \multirow{3}{*}{$\begin{array}{l}\text { 3D Yazılım } \\
\text { 3D Baskı }\end{array}$} & $\begin{array}{l}\text { Kalınlık } \\
\text { değişimi } \\
\text { İşlev }\end{array}$ \\
\hline & & & Form \\
\hline & & & $\begin{array}{l}\text { Dokusal } \\
\text { yüzey }\end{array}$ \\
\hline \multirow{3}{*}{ 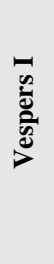 } & \multirow{3}{*}{$\begin{array}{l}\text { Mikro } \\
\text { Organizma } \\
\text { Doğal } \\
\text { Minareller }\end{array}$} & \multirow{3}{*}{$\begin{array}{l}\text { 3D Yazılım } \\
\text { 3D Baskı }\end{array}$} & $\begin{array}{l}\text { Karmaşık } \\
\text { Renk }\end{array}$ \\
\hline & & & Form \\
\hline & & & Hücresellik \\
\hline \multirow{3}{*}{ 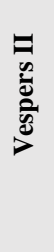 } & \multirow{3}{*}{$\begin{array}{l}\text { Başkalaşım } \\
\text { Nefes Alma }\end{array}$} & \multirow{3}{*}{$\begin{array}{l}\text { 3D Yazılım } \\
\text { 3D Baskı }\end{array}$} & $\begin{array}{l}\text { Heterojen } \\
\text { Renk }\end{array}$ \\
\hline & & & Form \\
\hline & & & Süreklilik \\
\hline \multirow{3}{*}{ 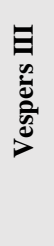 } & \multirow{3}{*}{ Nöro-vasküler } & \multirow{3}{*}{$\begin{array}{l}\text { 3D Yazılım } \\
\text { 3D Baskı }\end{array}$} & $\begin{array}{l}\text { Büyüme } \\
\text { Yönlenme }\end{array}$ \\
\hline & & & Form \\
\hline & & & Damarlaşma \\
\hline
\end{tabular}

\begin{tabular}{|c|c|c|c|}
\hline & $\begin{array}{l}\text { Biyoloji } \\
\text { (Organizma) }\end{array}$ & $\begin{array}{l}\text { Teknoloji } \\
\text { (Üretim) }\end{array}$ & Özellik \\
\hline \multirow{3}{*}{ 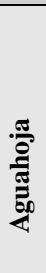 } & \multirow{3}{*}{$\begin{array}{l}\text { Deniz } \\
\text { Kabukları }\end{array}$} & \multirow{3}{*}{$\begin{array}{l}\text { 3D Yazılım } \\
\text { 3D Baskı }\end{array}$} & $\begin{array}{l}\text { Büyüme } \\
\text { Heterojen } \\
\text { Malzeme }\end{array}$ \\
\hline & & & Form \\
\hline & & & Hücresellik \\
\hline \multirow{3}{*}{ 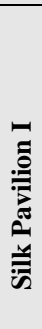 } & \multirow[t]{3}{*}{ İpek Böceği } & \multirow{3}{*}{$\begin{array}{l}\text { CNC } \\
\text { Biyolojik } \\
\text { Yazıcı } \\
\text { 3D Haritalama }\end{array}$} & $\begin{array}{l}\text { Işs1k } \\
\text { Isı } \\
\text { Dayanım } \\
\text { Başkalaşım }\end{array}$ \\
\hline & & & Form \\
\hline & & & $\mathrm{A} \breve{g}$ \\
\hline \multirow{3}{*}{ 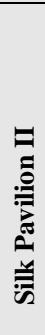 } & \multirow[t]{3}{*}{ İpek Böceği } & \multirow{3}{*}{$\begin{array}{l}\text { 3D Yazılım } \\
\text { 3D Bask1 } \\
\text { Canlı üretim }\end{array}$} & $\begin{array}{l}\text { Işı1k } \\
\text { Isı } \\
\text { Dayanım } \\
\text { Başkalaşım }\end{array}$ \\
\hline & & & Form \\
\hline & & & Eğrilik \\
\hline \multirow{3}{*}{ 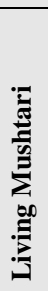 } & \multirow{3}{*}{$\begin{array}{l}\text { Mikro } \\
\text { Organizma } \\
\text { Algler } \\
\text { Bakteri }\end{array}$} & \multirow{3}{*}{$\begin{array}{l}\text { 3D Yazılım } \\
\text { 3D Baskı }\end{array}$} & $\begin{array}{l}\text { Heterojen } \\
\text { Değişken } \\
\text { Renk }\end{array}$ \\
\hline & & & Form \\
\hline & & & Damarlaşma \\
\hline \multirow[t]{3}{*}{ } & \multirow[t]{3}{*}{ Rahim } & \multirow{3}{*}{$\begin{array}{l}\text { Stratasys'in } \\
\text { Connex3 } \\
\text { teknolojisi } \\
\text { CNC }\end{array}$} & $\begin{array}{l}\text { Dayanım } \\
\text { Karmaşık } \\
\text { Akustik }\end{array}$ \\
\hline & & & Form \\
\hline & & & Dokusal Yüzey \\
\hline & \multicolumn{3}{|c|}{$\begin{array}{l}\text { Biyoloji, teknoloji kesişimde tasarım } \\
\text { cesini etkileyerek formu oluşturan yaklaşım; } \\
\text { Hesaplama" olarak ifade edilmektedir. }\end{array}$} \\
\hline
\end{tabular}




\section{Sonuç ve Öneriler}

Neri Oxman; farklı disiplinlerden aldığı eğitimle beraber farklı tasarım düşüncesi geliştirerek doğayı kullanım şeklinde özgün bir yöntem geliştirmiştir. Multidisipliner çalışma alanında farklı ölçeklerde çalışarak deneyimlediği dijital süreçleri, biyoloji ve teknoloji kesişiminde kademe kademe ilerlediği görülmektedir. Bu kademelerdeki formsal gelişimler, malzemeye bağlı olarak etkilendikleri ve geliştirdikleri organizmaların davranışlarına göre değişkenlik gösterdiği görülmektedir. $\mathrm{Bu}$ bağlamda çalışmalarında özellikle en etkili olduğu parametre; organizma, organizmanın davranışı, organizmadan elde edilen dönüşebilir malzeme ve formsal özelliklerdir. Formun malzemenin özelliklerine göre heterojen bir dağılımla oluştuğu ve farklı bölgelerde farklı davranış gösterdiği örneklem bağlamındaki incelemelerde dikkat çekmektedir. Tasarımın kendi içindeki sistemindeki parçalanma, tasarım bütününe yansımamaktadır. Bu durum ise Oxman'ın tasarım düşüncesinin temelinde yer alan "yaşayan şeyler oyulmazlar, büyürler, farklılaşırlar ancak yine de bütündürler" ifadesinde de görülmektedir. Bu bağlamda tasarım düşüncesini oluşturan biyo hesaplama yaklaşımı, tasarım çıktılarında form, malzeme, teknik, üretim gibi tüm süreci kapsayan bir anlayış olduğu görülmektedir.

Monocoque, Raycounting, Cartesıan Wax, Vespers I, Vespers II, Vespers III daha çok düşünce alt yapısı ve fiziksel verilerle araştırma alanlarını genişleterek malzeme ve form ilişkisi açısından destekleyici çalışmalardır. Bu araştırmalar geleceğe yönelik gelişimleri destekleyici, farklı projeler için bir zemin hazırlayan ufuk açıcı bir bakış kazandırmak için geliştirilen alandır. Ancak Aguahoja, Silk Pavilion I, Silk Pavilion II, Living Mushtari ve Gemini gibi çalışmalar ise, biyoloji ve teknolojinin tasarım sürecinden üretim sürecine kadar olan kesişiminin somut örnekleridir. Komplekstir ancak sınırsız araştırma ve geliştirme konularını içinde barındırarak bir hikâye ortaya koymaktadır. Bilimsel alt yapının tasarımla bütünleştiği bu çalışmalar, farklı ölçeklerde ve farklı problemlere yönelik çözümler üretmektedir. Ortak özellikleri ise yaşayan bir organizamanın davranış süreci içerisindeki üretken olma durumunu kapsamaktadır. $\mathrm{Bu}$ nedenle biyolojik sürecin dijital araç ve birikimle beraber ortak çalıştığı ve tasarımın sürekli kendi içindeki evrimleşmesinin devam ettiği bir birikim geliştirir. Bu durum diğer tasarım yaklaşımlarından farklılaşarak kendine özgü bir yapı kazandırır.

Neri Oxman'ın tasarım yaklaşımındaki hikayesel bir başlangıcın belirli bir bilimsel veriye dayandığını görmekteyiz. Bu veri, tasarımda hem form, hem de malzeme olarak geliştirilmektedir. Oxman'ın tasarımlarında doğadan sadece ilham almak değil aynı zamanda oluşturduğu bakış 
açısıyla da doğadan bir mesaj verdiği görülmektedir. Deniz kabuklularının çürümesi yerine onu yenilebilir bir malzemeye dönüştürmesi ve kirliliği önlemeye çalışması, aynı şekilde ipek böceklerini öldürerek elde edilen malzemenin onların davranışlarını geliştirerek de elde edilebileceğini vurgulayarak doğayı iyileştirme yönündeki adımlarını görmekteyiz. Bu anlamda da tasarım yaklaşımındaki doğanın ve organizmaların yerinin ne kadar önemli olduğu ve doğanın sadece ilham alarak değil aynı zamanda öğrenilmesi gerektiğini yansıtmaktadır.

Biyoloji ve teknoloji kesişimiyle tasarım süreçlerini tanımlayan Oxman, gerek doğayı kullanış biçimi, verdiği mesajı, gerekse ürettiği bilimsel verilerle tasarımlara yansıtması yönünden önemli bir tasarımcıdır. Uzaydan, iklim değişikliğine kadar farklı problemlere çözümü, doğayı dijital araçlarla araştırarak bulmaya çalışmaktadır. Bu araştırmaların geleceğe yönelik mimari ve tasarım disiplinlerine yeni bakış kazandıracağı görülmektedir. 21. Yüzyılda araştırma alanlarındaki bu multidisipliner bakış açısı; doğa merkezli ve teknolojiyi araç olarak kullanan bir yaklaşım olarak önem kazanmaktadır. Bu bağlamda ortaya koyduğu biyo hesaplama yaklaşım, biyoloji ve teknoloji kesişiminin bir ürünü ve yenilikçi tasarım düşüncesinin temeli olması sebebiyle araştırma alanlarına ilham olmaktadir.

\section{Yazarların Katkısı}

Çalışmada her yazar eşit oranda katkı sunmuştur.

\section{Çıkar Çatışması Beyanı}

Yazarlar arasında herhangi bir çıkar çatışması bulunmamaktadır.

\section{Araştırma ve Yayın Etiği Beyanı}

Yapılan çalışmada, araştırma ve yayın etiğine uyulmuştur.

\section{Kaynaklar}

Bader,C., Patrick,W. P., Kolb,D., Hays,S. G., Keating,S., Sharma,S., Dikovsky,D., Belocon,B., Weaver, J.C., Silver,P, A., and Oxman N., (2016). Grown, Printed, and Biologically Augmented: An Additively Manufactured Microfluidic Wearable, Functionally Templated for Synthetic Microbes. $3 D$ Printing And Additive Manufacturing, Volume 3, Number 2, 2016, Mary Ann Liebert, Inc.

Benyus, J., (1997). Biomimicry: Innovation Inspired by Nature. William Morrow Company Inc. NewYork. Berkebile, B., McLennan, J., (2004). The Living Building: Biomimicry in Architecture, Integrating Technology with Nature. BioInspire

Clarke, A. C., (1964). Opening speech of the General Motors Pavilion World Fair. New York. 
Tavşan, C., ve ark., Uluslararası Doğu Anadolu Fen Mühendislik ve Tasarım Dergisi / International Journal of Eastern Anatolia Science Engineering and Design (IJEASED)

(2021) 3(2): 405-424

Çelenk, A., (2020). 21. Yüzyıl Mimarlığında Biyo-Dijital Tasarımla Form Analizi. Yüksek Lisans Tezi, Karadeniz Teknik Üniversitesi, Fen Bilimleri Enstitüsü, Trabzon

Duro-Royoa, J, Zolotovsky K., Mogas-Soldevila L.,Varshneyc, S., Oxman, N., Boyce, M. C., Ortiz, C., (2015). MetaMesh: A hierarchical computational model for design and fabrication of biomimetic armored surfaces. Computer-Aided Design 60, 14-27.

Kallegias, A., ve Erdine, E., (2015). Design by Nature: Concrete Infiltrations. Generative Design - Applied Volume 2 - eCAADe 33, 513-520

Khanzadeh M, (2019). Bio Design Method; Learning Nature In Line With Technology, Journal of Environmental and Natural Studies, Volume, 1, Issue 1, Pages, 11-18

Marx, K., (2015). Kapital. İstanbul: Yordam Kitapevi.

Myers, W., (2012). BioDesign: Nature Science Creativity. MoMa, New York, USA.

Oxman, N., Royo, J., Soldevila, L.M., (2015). Flow-Based Fabrication: An Integrated Computational Workflow for Design and Digital Additive Manufacturing of Multifunctional Heterogeneously Structured Objects. Computer-Aided Design Journal, Elsevier 2015 Special Issue on Geometric and Physical Modeling for Additive Manufacturing.

Oxman, N., Laucks, J., Kayser, M., Duro-Royo, J., Gonzales-Uribe C., (2014). Silk Pavilion: A Case Study in Fiber-based Digital Fabrication. FABRICATE Conference Proceedings, Fabio Gramazio, Matthias Kohler, Silke Lan enber (eds.) ta Verla, 248-255.

Sennet, R., (2013). Zanaatkar (2.Basım). İstanbul: Ayrıntı Yayınları.

Sorguç, A. Ve Memişçioğlu, M., (2020). Mimarlıkta Fabrikasyon Teknolojileri ve Endüstri/Mimarlık 4.0. dosya 45, Gelecek, Teknoloji ve Mimarlık, TMMOB Mimarlar Odası Ankara Şubesi

Sugár, V., Leczovics, P. and, Horkai, A., (2017). Bionics in architecture. Ybl Journal of Bullt Environment Vol. 5 Issue 1.

URL-1:https://www.surfacemag.com/articles/neri-oxman-material-ecology/ (ErișimTarihi: 24.03.2021)

URL-2: https://oxman.com/(Erişim Tarihi: 24.03.2021)

URL-3: https://oxman.com/projects/monocoque (Erişim Tarihi: 24.03.2021)

URL-4: https://oxman.com/projects/raycounting (Erişim Tarihi: 24.03.2021)

URL-5: https://oxman.com/projects/cartesian-wax (Erişim Tarihi: 24.03.2021)

URL-6: https://oxman.com/projects/vespers-i (Erişim Tarihi: 24.03.2021)

URL-7: https://oxman.com/projects/vespers-ii (Erişim Tarihi: 24.03.2021)

URL-8: https://oxman.com/projects/vespers-iii (Erişim Tarihi: 24.03.2021)

URL-9: https://oxman.com/projects/aguahoja (Erişim Tarihi: 24.03.2021)

URL-10: https://oxman.com/projects/silk-pavilion-i (Erişim Tarihi: 24.03.2021)

URL-11: https://oxman.com/projects/co-fabrication-systems (Erişim Tarihi: 24.03.2021)

URL-12: https://www.media.mit.edu/projects/living-mushtari/overview/(Erişim Tarihi: 24.03.2021)

URL-13: https://www.media.mit.edu/projects/gemini/overview/ (Erişim Tarihi: 24.03.2021)

URL-14: https://www.domusweb.it/en/biographies/neri-oxman.html (Erişim Tarihi: 29.06.2021)

Vorobyeva, O, I., (2018). Bionic architecture: back to the origins and a step forward. IOP Conf. Ser.: Mater. Sci. Eng. 451012145.

Whitehead, A., N., (2017). Doğa Kavramı. İstanbul:Alfa Yayıncılık.

Yedekçi, G., (2015). Doğayla Tasarlamak: Biyomimikri ve Geleceğin Mimarlı̆̆̆. İstanbul: Mimarlık Vakfı İktisadi İşletmesi. 